\title{
WORKING THROUGH STATE DIFFERENCES TO CREATE A REGIONAL DREDGED MATERIAL MANAGEMENT PLAN FOR FEDERAL HARBORS IN LONG ISLAND SOUND
}

\author{
Mark Habel, U.S. Army Corps of Engineers New England District, Mark.L.Habel@usace.army.mil \\ Meghan Quinn, P.E., U.S. Army Corps of Engineers Cold Regions Research and Engineering Laboratory, \\ Meghan.C.Quinn@usace.army.mil
}

ABSTRACT

On January 11, 2016 the U.S. Army Corps of Engineers (USACE) New England District (NAE) completed a Final Dredged Material Management Plan (DMMP) for Long Island Sound (LIS). The DMMP was requested by the Governors of Connecticut and New York, in their letter of February 8, 2005 to the Chief of Engineers, following the U.S. Environmental Protection Agency's (EPA) publication in April 2004 of the Long Island Sound Dredged Material Disposal Site Designation Study Final Environmental Impact Statement.

The LIS is a large coastal estuary located between Long Island, New York on the south, and the shores of New York, Connecticut and southwestern Rhode Island on the north. A total of nearly 240 harbors, coves, bays and rivers supporting various levels of navigational access are located along these shores. Twelve Congressional districts and 112 municipalities border the Sound and its adjacent waters in the three states. The ideals, goals, and needs along the LIS do not always align and thus the need for open communication throughout each dredging project.

The USACE investigated over 50 Federal Navigation Projects (FNPs) with 31 Connecticut projects, 17 in New York, and four in Rhode Island. Fourteen Connecticut projects are deep draft with authorized depths of 15 feet or greater with four having maintained depths of 35 feet or greater. Dredging is necessary for the continued maintenance and occasional improvement of these harbors to maintain safe navigation. Where to place and how to best use dredged material from harbors in and around the Sound has been an increasingly contentious issue.

This DMMP examines past dredging history, future dredging needs, dredged material placement, and current beneficial use practices. The DMMP identifies and assesses alternatives for future dredged material placement and beneficial use for each Federal project and separable component, and identifies the likely Federal Base Plans (FBPs) for future FNP dredging activities. This methodology is meant to promote understanding between governments and communities along the LIS on realistic dredging options and costs.

Beneficial use project costs exceeding the cost of the FBP option become either a shared Federal and non-Federal responsibility, or entirely a non-Federal responsibility, depending on the type of beneficial use.

To keep open lines of communication throughout DMMP development, NAE and EPA-I established an interagency Project Delivery Team (PDT); conducted public scoping meetings in CT and NY to solicit public input; and established a technical working group including the PDT members and other local and regional stakeholders, non-governmental organizations (NGOs), universities and marine commercial interests. These groups worked to formulate a range of alternatives for evaluation including current and historic open water placement sites, beach and nearshore nourishment sites, upland landfills, island and shoreline confined disposal facilities, confined aquatic disposal cells, confined open water sites, onshore dewatering/processing areas, marsh creation and enhancement sites, and other applications for dredged material use.

The DMMP recommended the continuation and creation of a Regional Dredge Team (RDT), specific for the LIS, so that the States may continue to work out their differences in the future. Although the RDT will not have Federal authority, the collaborative nature of the team should provide the agencies with more information and greater options for evaluations and decision-making on the projects and applications for approval before action. The RDT should review the alternatives analysis for all projects submitted for its consideration and input, to help ensure that practicable alternatives as described in the DMMP for each harbor and dredging center have been thoroughly evaluated and are implemented where practicable.

Continued communication between the States and Federal agencies remains the greatest means of shared understanding and commitment towards the keeping our ports and harbors operational, our coastal waters clean, and our shorelines resilient.

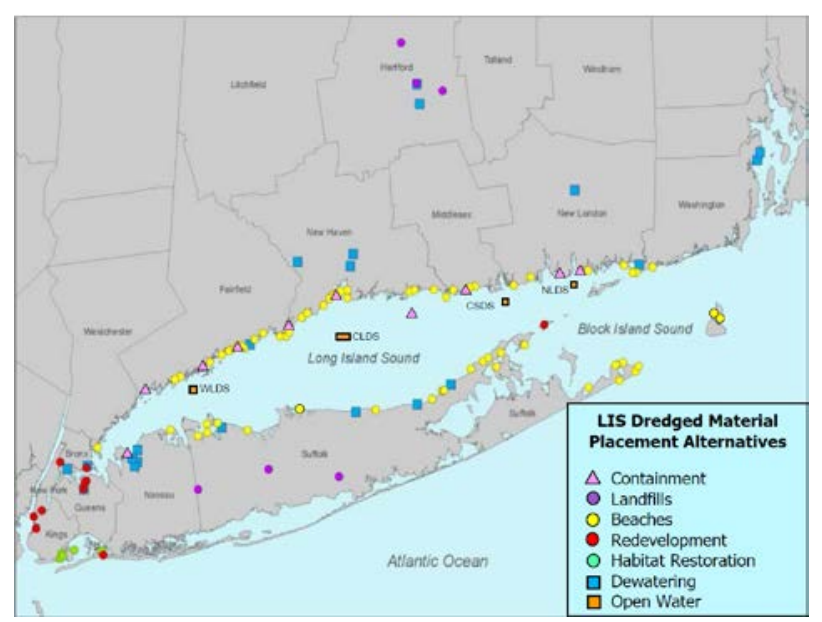

Figure 1 - LIS DMMP placement alternatives

\section{REFERENCES}

USACE (2009) Long Island Sound Dredged Material Management Plan - Dredging Needs Report, Final

Report.

USACE (2009) Long Island Sound Dredged Material

Management Plan - Upland, Beneficial Use, and

Sediment De-watering Site Inventory (Phase 1)

USACE (2010) Long Island Sound Dredged Material

Management Plan (DMMP) - Phase 2 Literature Review Update.

USACE (2016) Final Long Island Sound Dredged Material Management Plan. 